\title{
An approach to the Principles of Latin American Contract Law's development and their contract remedies
}

\section{Alfredo Ferrante}

\author{
Faculty of Law, \\ University Alberto Hurtado, \\ Santiago de Chile, Chile \\ Email: aferrante@uahurtado.cl
}

\begin{abstract}
The purpose of the paper is to provide an overview of the remedial system provided by the Principles of Latin American Contract Law. After introducing the process of drafting the principles, the paper makes some general considerations regarding contractual remedies in this new instrument of soft law. Specifically, the process of adoption of it will be analysed, including not only the adopted remedies but those that were eliminated although initially provided in the drafts of the project.
\end{abstract}

Keywords: contract; Latin American Contract Law; remedies; sale of goods.

Reference to this paper should be made as follows: Ferrante, A. (2020) 'An approach to the Principles of Latin American Contract Law's development and their contract remedies', Int. J. Private Law, Vol. 9, No. 4, pp.259-271.

Biographical notes: Alfredo Ferrante is currently the Director of the Department of Private Law of University Alberto Hurtado (Chile) and former Professor at the University of Oviedo and Girona. He received his Doctor in Law from University of Oviedo (Spain), with honours and Bachelor of Laws from University of Pisa (Italy) and Oviedo. He is a Visiting Researcher in the University of Columbia, Max Planck Institute, Swiss Institute of Comparative Law and Sorbonne University and Visiting Professor in the University of Brescia and University Paris XII (Nanterre).

\section{Introduction}

Given the undoubted importance of commercial contracting in the international arena and the undoubted role that the Unidroit Principles and the Vienna Convention play in the legal landscape for the regulation of cross-border contracts, it was necessary to work on a unifying text for Latin America that fulfil a similar function. The growing development of regional trade, generated concern for considering a common regulation, taking advantage of the presence of a single thread of its legal culture and the language unit of the continent. In that context, in January 2018 the text of the Principles of Latin American Contract Law (PLACL) was officially presented ${ }^{1}$ and published, ${ }^{2}$ not only in Spanish but also in English, French, and Italian. In the following pages, after briefly introducing the process of drafting them, some general considerations will be made regarding contractual remedies ${ }^{3}$ as an introduction to this new text. 


\section{The process of creation and function}

After nine years of meetings and activities, which were spearheaded by the constant work of the group's coordinator, Prof. Carlos Pizarro, and assisted by Prof. Claudia Bahamondes, ${ }^{4}$ the work of academics from universities in Argentina, Brazil, Colombia, Chile, France, Guatemala, Paraguay, Uruguay, and Venezuela was completed.

Essentially, the text was developed in two stages: first, a questionnaire ${ }^{5}$ was created and completed by each country; second, the completed questionnaires served as a background for the creation of a text that, in its final version, contains 123 articles.

The group met almost annually ${ }^{6}$ and, during PLACL's development, there were three prior drafts. The first one was presented, without numbered provisions, in two congresses, in $2012^{7}$ and $2013 .^{8}$ Then it progressed to an outline draft of 111 articles in $2014^{9}$ and to a third draft of 120 articles in October $2015^{10}$

The final text has also been developed through the submission of drafts for criticism and feedback at several ad hoc international events, specifically in United Kingdom, ${ }^{11}$ Spain, ${ }^{12}$ and Chile. ${ }^{13}$

Throughout this process, the scholars addressed, prior to the final version, issues such as good faith, ${ }^{14}$ price reduction, ${ }^{15}$ (non-)performance and means of relief, ${ }^{16}$ mistake, and initial impossibility. ${ }^{17}$ More generally, it addressed contract defects, ${ }^{18}$ la laesio,${ }^{19}$ the concept of contract and its elements, ${ }^{20}$ and formation of contract, ${ }^{21}$ as well as considered a general overview, ${ }^{22}$ the European harmonisation process, ${ }^{23}$ and United Nations Convention on Contracts for the International Sale of Goods (CISG). ${ }^{24}$

As the coordinator of the group, Carlos Pizarro explained that the project was initiated at the International Congress on the Transformations of Contract Law between France and Latin America, which was held in Rennes in $2009 .^{25}$

The Fondation pour le Droit Continental and the Fundación Fueyo Laneri (Universidad Diego Portales) $^{26}$ have played a fundamental role in the sponsorship of the project, which essentially has two purposes.

The aims of the project are to identify and highlight the Latin American legal identity and, at the same time, to innovate $i ;^{27}$ an attempt has been made not only to rescue Latin America's own legal culture, but also to provide an instrument that translates the jurisprudential and doctrinal evolutions that have been consolidated over the decades and that also offer a modern vision of the legal reality of contract rights.

Thus, 'our objective could never have been to create a model code or an idea of uniformity in contract law. The objective therefore was (...) provide inspiration or better solution for courts and judges in the name of lex mercatoria, ${ }^{28}$ an aspect that is expressly reflected in article $2 .^{29}$

Most of the Latin American civil codes have remained largely unamended, except for reforms in Brazil ${ }^{30}$ and Argentina ${ }^{31}$ that have partially restructured the work developed by Dalmacio Vélez Sarsfield or Augusto Teixeira de Freitas who, together with Andres Bello, played an unquestionable role in the codification of the Latin American process. ${ }^{32}$

Bello's Code of 1855, drawn up long before many European codes, has substantially influenced many of the Latin American countries that were initially involved in PLACL. ${ }^{33}$

It is striking that Bello's Code has been considered an untouchable code and that any reforms have occurred through individual practices, leaving intact the law of obligations and contract. In this sense, there is even more justification for the establishment of 
Principles that try to revisit the current situation and deliver a future model for all legal operators that freely wish to adopt them.

Latin America's common language of Spanish and the previous European and international models of harmonization or unification (v.gr. CISG, Principles of European Contract Law - PECL - UNIDROIT Principles for International Commercial Contracts: UPICC) have been a facilitating and accelerating vehicle for a process that, for this reason, should not have taken almost a quarter of a century to occur after it happened in Europe. $^{34}$

Before analysing contractual remedies, it is also appropriate to note that PLACL has identified three supra-criteria that serve to resolve doubts in the application of its provisions. Therefore, there are three express 'general principles of principles' that are fundamental: freedom of contract (art. 5), binding force of contract (art. 6), ${ }^{35}$ and good faith (art. 7).

The inclusion of these supra-criteria is thought to record the principles that clearly frame the tradition of civil law, although they are also expressly included in other provisions. ${ }^{36}$ This does not mean that criteria properly characteristic of the common law were adopted by PLACL, such as the reference to reasonableness, although it appears they have been in a limited way. ${ }^{37}$

\section{Performance and non-performance}

In the first draft, one of the radical changes from the traditional Latin American vision is the incorporation of express definitions of performance (art. 77) and non-performance (art. 85) that essentially mirror each other.

One of the most important issues that have generated a long debate in the study group has been performance to adopt.

The adoption of subjective performance would have made the fault of the parties relevant and provided a system of special means of relief as opposed to objective performance, which dispenses with fault and adopts only a general system of means of relief.

The practical consequences of the choice affect the theory of risks and the role of initial impossibility. Adopting the objective non-performance implies their absorption in non-performance. On the other hand, according to the subjective non-performance, the initial impossibility would cause the lack of purpose and therefore the absolute nullity of the contract.

Finally, another consequence of adopting an objective conception is to move away from a system of exoneration in the case of an Act of God. In this case, an Act of God does not eliminate the exercise of the means of relief applicable to the specific case. ${ }^{38}$

The difference between the obligation and responsibility of the subject is clearly highlighted, and PLACL adopts a more favourable view to the obligee. In case of an objective impossibility ${ }^{39}$ of performance, the obligee will have a whole series of remedies dispensing with the obligor's fault. Therefore, an Act of God will not operate as an exemption from liability but will only serve to avoid imposition of damages against the obligor.

A broad concept of non-performance is also adopted, based on CISG's influence (art. 87 PLACL). 
It has been discussed ${ }^{40}$ whether to add late performance, although it has not been finally introduced. However, it was agreed that a note in future official comments should clarify that the broad notion of non-performance includes three modalities: nonperformance, late performance, and defective performance. ${ }^{41}$ With respect to the first draft, the definition of 'defective performance' (old art. 7.5 unpublished draft in performance section) has been omitted.

\section{Contractual means of relief system}

The study group analysed ${ }^{42}$ the restructuring of the contractual means of relief in favour of the obligee and assessed whether priority should be given to specific performance over other means or whether to disassociate from this hierarchy, even allowing for damages to be claimed separately (or in conjunction) with the remaining means of relief.

The traditional remedial system of contractual liability, which essentially (and expressly) provided for the priority of specific performance or termination of the contract (and damages), is abandoned. In this sense, the range of means of relief is extended for all contracts, and there is a choice between

1 specific performance

2 price reduction

3 termination of the contract

4 suspension of performance ${ }^{43}$ and

5 damages (art. 91).

Article 91 does not really provide for a free choice between them because it states that 'the obligee may, at its discretion and as appropriate, exercise...'.

Thus, the discretion is limited by certain incompatibilities (nachfrist: art. 93 (2), price reduction: art. 96 (2)) or by the onus to exercise the means of relief because the obligee may not demand performance or termination of contract if he has not given notice of the non-conforming performance within a reasonable time after he should have become aware of it (art. 92).

There are also some express limitations in the case of non-performance that is not fundamental. In this case, the replacement (not the repair) cannot be exercised [art. 95 (2)] because this is often more costly than repair. ${ }^{44}$ Also, termination of a contract requires a fundamental non-performance [art. 97(1)], an aspect not expressly regulated in the codes but nonetheless accepted unanimously by the évolution prétorienne. ${ }^{45}$

Another novel aspect of Latin American systems is the express regulation of gross disparity and, if the performance is extremely burdensome for the obligor, this operates as a limitation on performance [cf art. 84, art. 94(2)]. ${ }^{46}$ Specific performance has also another limitation: "it may not be demanded when it represents an injury to personal dignity’ [art. 94 (2-c)].

Based on European influences, it is important to emphasise that another means of relief cannot be demanded if the obligor has another means of relief suitable to satisfy the interest of the obligor. PLACL also establishes some express compatibilities in relation to damages [art. 91 (2), art. 93 (2)], or penalty clause (arts. 115 and 116). 


\subsection{Specific performance}

The contract may also be performed by a third party (art. 82) ${ }^{47}$ and PLACL clearly identifies repair and replacement within specific performance, despite not expressly cataloguing them within the means of relief (cf art. 91, 94, and 95).

\subsection{Termination of contract and price reduction}

Termination may be determined by a court or by notice (it shall be effective upon receipt, art. 98), and it is expressly provided that it can occur only in a case of fundamental nonperformance. Another important novelty is that 'reciprocal non-performance shall not prevent the termination of the contract' (art. 97.2). The effects of termination and nullity are put together as in new French civil code's general system of (cf arts. 119-123 PLACL; arts. 1352-1352-9 Frcc).

It is also important to highlight that an express provision regarding the partial resolution initially contained in the 2012 draft was eliminated and now there is a change of vision because for article 99 (1): 'termination extinguishes the effects of a contract, unless it is partial'. ${ }^{48}$

Price reduction is also renewed and consolidated as a means of relief for all contracts. Despite the adoption of a calculation method similar to CISG (cf art. 96 PLACL, art. 50 CISG), the judge may adopt another method of calculation. ${ }^{49}$

\subsection{Damages}

As for damages, it should be noted that its full autonomy [art. 91 (2)] is expressly provided for with respect to the other remedies, reflecting a reinterpretation that modern doctrine and jurisprudence have made of the literalness of Latin American provisions. ${ }^{50}$

In the meetings in Santiago (2016) and Bogotà (2017), ${ }^{51}$ the drafting of the rules was simplified and perfected, and now it is clearly stated that 'the recovery of damages covers monetary and non-monetary harm' (art. 105). ${ }^{52}$

For damages, three important provisions are referenced: the foreseeability of harm (art. 107), the contribution of the obligee to its harm (art. 108), and the mitigation of loss (art. 109).

A damages limitation is established 'for the harm at the time of conclusion of the contract and that results from its non-performance', excluding damages 'in the event of fraud or gross negligence of the obligor' (art. 107). In these provisions, a norm of predictability that is characteristic of Latin American culture, ${ }^{53}$ of French influence ${ }^{54}$ and also used in a modern soft law instruments. ${ }^{55}$

However, when adopting a concept of objective non-performance, all references to default ${ }^{56}$ are left behind, making it explicit that '[i]f non-performance is the result of an Act of God, there shall be no grounds for damages' (art. 104.2).

PLACL introduces the reduction of compensation when the obligee has contributed to the non-performance, adopting a principle consolidated by Bello in matters of extracontractual liability ${ }^{57}$ and that is characteristic of modern European law of obligations. $^{58}$

Finally, the text introduces the mitigation of loss, a totally innovative aspect for Latin American law, ${ }^{59}$ intermingling the positions of European reform proposals. ${ }^{60}$ 
'If non-performance is the result of an Act of God, there shall be no grounds for damages', although the obligor's conduct influences his responsibility by expanding the content of damages in the event of fraud or gross negligence, limiting that of the other party if he is not proactive, and complementing the limitation imposed by nonperformance due to the obligee's own acts or omissions, which prevents the use of means of relief. ${ }^{61}$

\subsection{Substitute transaction}

In the Santiago meeting in $2016,{ }^{62}$ the substitute transaction was eliminated (art. $103 \mathrm{draft}$ 2014; art. 112 draft 2015).

Originally the justification that was indicated to introduce it, was the supposed greater facility of the calculation of the damages. However, it was preferred not to introduce it since the calculation does not turn out to be complex, since the same result is reached by adding up the amounts of money that are produced by the restorative effects of the resolution and the amount of damages.

Although the PLACL does not foresee it, the express existence in the Latin American Codes of the differentiation between loss in profit and consequential damages, turns out to be sufficient not to introduce a foreign and unknown institution such as the substitute transaction, preferring the traditional use of national regulations. The possibility of requesting a termination (which, for its effects, will return what it has already been paid) plus the consequential damages, that is, the effective decrease in assets (the overprice paid for the replacement object) replaces, in Latin American systems, the Substitute transaction and so it has been considered not to introduce it. ${ }^{63}$

Here, CISG's influence (arts. 75 and 76) gives way to a simpler text that, from the civil law system, produces an identical calculation, with institutions of civil law and of broad knowledge in Latin America.

Likewise, it was considered ${ }^{64}$ that if PLACL did not want to introduce calculation methods in other more complex circumstances - such as loss in profit or loss of opportunity - a fortiori it was not appropriate to do so in this case. Although PLACL provide for a termination by notice (cf. art. 98) - which could justify a rule on substitute transaction - finally, it has been considered not to include it because it is a trendfully distant institution from the tradition of Latin American legal systems.

\subsection{Commodum representationis}

Although not expressly included in art. 91, there is another means of relief: commodum representationis [art. $94(2-\mathrm{a})$ ], that is, the obligee may require that non-performing party assign its rights and actions against third parties. In this sense the provision, of French influence (cf old article 1303 Frcc; new article 1351-1 Frcc) is extended respect to the only application in case of loss of good (v.gr. as in art. 1677 Chec and art. 1736 Colcc).

\subsection{Nachfrist}

One of the innovations introduced in the last meeting of the Principles is the period for cure contained in article 93, which is not a Latin American feature. This provision is introduced to favour the obligor to avoid a group of means of relief and a concept of non-performance pro creditore. ${ }^{65}$ 
So 'unless non-performance is fundamental, the obligee must allow an additional period of reasonable length to cure non-performance' [cf 93 (1)].

The term allows the obligor to cure and avoid the obligor's means of relief, notwithstanding its right to claim damages. A cure period of German origin (nachfrist) was chosen. Although a cure period is only a possibility in CISG (art. 47 'The buyer may fix'), PLACL transforms it into an obligation ('the obligee must allow', art. 93 PLACL). This change eliminates the possibility that the obligor proposes a new period (cf art. 63 CISG), but a further offer to cure (except in the case of an essential term) should be accepted based on the principle of good faith.

The reference to the 'period of reasonable length for cure' in article 93 emphasises that any express term in relation to performance is eliminated.

Prior to the $2013 \mathrm{draft}$, article 92 provided that 'the period may never exceed two years from the execution of performance'. Also, it was provided that when terminating a contract, 'if the performance is imperfect, the notice must be made within a period of 15 days from the notice of art. XX'. Now, all references to a specific time period to cure are eliminated $^{66}$ to give greater elasticity to the system (cf arts. 97 and 98).

\section{Conclusions}

There are two points to understand about Latin American law: the importance of the French influence and the existence of a model, the Bello's Code, that has prevailed in many countries. ${ }^{67}$

However, the dissemination in Latin America of the European unification movements imposed the need to rethink some visions and understand that, in the context of modernisation of the law of obligations, it was appropriate to modify the rules of the 19th century. Additionally, since PLACL's process began, the Argentine ${ }^{68}$ and French ${ }^{69}$ civil codes have been reformed.

The CISG or other instruments such as UPICC, PECL, and DCFR influenced this process. All of this is also reflected in the contractual remedial system. It must be understood that America is a continent that was created through European colonisation and that the law in Latin America did not originate on its own (except for indigenous law).$^{70}$ This is reflected somewhat in the current PLACL.

Although PLACL does not reflect all Latin American countries, as an academic reference text, it can be a model for Latin American legislators and can be used in arbitration, as an alternative to $19^{\text {th }}$ century Latin American codes.

That is why PLACL has renewed stagnant codes, in which there has been little reform due to the absence of an effective legislative institution ${ }^{71}$ or political instrument (such as, mutatis mutandis, the European Union), despite the advantage of Latin American countries sharing a common language.

\section{Notes}

1 In the Real Academia Española de Jurisprudencia y Legislación, Madrid, 9.1.2018.

2 De la Maza Gazmuri, I., Pizarro Wilson, C, and Vidal Olivares, A. (2018) Los Principios Latino Americanos de Derecho de los Contratos, Madrid, BOE. 
3 Since the beginning, it was preferred to use the expression 'means of relief' instead of 'remedies' because the second term is more consistent with the common law tutelage and the first one is more specific to continental countries. The expression 'remedies' rather derives from a Latin root and from the Anglo-Norman dialect rooted in the Law French, language used until the middle of the 18th century: see Adams, J., The Law French Dictionary. Alphabetically Digested: Very Useful for all Young student in the Common Laws of England (London, Isaac Cleave and John Hartley, 1718) and Guarnieri, A., Lineamenti di diritto comparato (Padova, Cedam, VII ed., 2016), 272 ss; S Ferreri, Silvia, 'Law French' [2009] Dig. Disc. Priv., sez. Priv., Aggiornamento, IV, 322 ss.

4 The Fueyo Laneri Foundation is thanked for the access to the study group's meeting minutes since they are unpublished.

5 The questionnaire is published in C. Pizarro Wilson (Ed), El Derecho de los Contratos en Latinoamérica (Bases Para Unos principios de Derecho de los Contratos), (Bogota, Universidad Externado and Universidad del Rosario de Colombia, Santiago de Chile, Fundación Fueyo Laneri, 2012).

6 First meeting: Bogota, Universidades del Externado (UEx) and Universidad del Rosario de Colombia (UR), 6-7.12.2010); second meeting: Santiago de Chile, Universidad Diego Portales (UDP), 3-4.10.2011). No meeting in 2012 (publication of the questionnaire). Third: Buenos Aires, Universidad de Buenos Aires, 2527.3.2013), 4th and 5th: Bogota, UEx and UR, 5-9.11.2013 and 26-28.8.2014; 6th: Santiago de Chile, UDP, 8-10.10.2014); 7th: Bogota, UEx and UR, 27-29.10.2015); 8th: Santiago de Chile, UDP, 9-11.8.2016), 8th: Bogota, UEx, 21-22.8.2017).

7 Catedra Fernando Fueyo 28.11.2012, UDP, Santiago de Chile.

8 'Congreso Internacional Derecho de los Contratos (Formación, cumplimiento e incumplimiento)', 19-20.11.2013 UDP (Santiago de Chile), and Pontificia Universidad Católica de Valparaíso (PUCV). For a review and draft text: AM Morales Moreno, 'Los principios latinoamericanos de derecho de los contratos: un debate abierto sobre las grandes cuestiones jurídicas de la contratación’ (2014) 67 Anuario de Derecho civil, n. 1, 227 ss.

9 The English and Spanish text in R. Momberg and S. Vogenauer (2017) (Eds.): The Future of Contract Law in Latin America. The Principles of Latin American Contract Law (Oxford and Portland Oregon, Hart Publishing), pp.285-312.

10 Spanish text in (2016) 69 Anuario de Derecho Civil, n. 3, 1012-1038.

11 In this case draft 2014 was analysed in Oxford. See R. Momberg and S. Vogenauer (n. 9). For a review: B. Gregoraci Fernández, 'The Future of Contract Law in Latin America, 25 de Junio de 2015, Institute of European and Comparative Law, University of Oxford (Reino Unido)', (2015) 68 Anuario de Derecho Civil, n. 3, 1083-1090; ME Morales Ortiz, 'Informe sobre Conferencia Internacional (The future of Contract law in Latin America)' (2015) 2 Revista derecho Civil, n. 3, pp.221-225; C. Ramberg, 'Principles of Latin American contract law: conference notes', (2016) 21 Uniform Law Review, n. 1, 1 March, 129-136; PR Borges Fortes, 'The future of contract in latinamerica', (2016) 24 European review of private law, 287-296. 
12 In this event draft 2015 was analysed in Madrid. For a review: L.P. San Miguel Pradera, 'Los Principios latinoamericanos de Derecho de los contratos: una revisión crítica. Jornadas de Discusión y análisis. Madrid, 16 y 17 de Junio de 2016. Real Academia de Jurisprudencia y Legislación', en (2016) 69 Anuario de Derecho Civil, n. 3, 991 y ss.

13 In this case draft 2015 was analysed. Congreso 'Los Principios Latinos Americanos de Derecho de Contratos', PUCV, 11-12.7.2017.

14 C Eyzaguirre Baeza and J Rodríguez Díez, 'Expansión y límites de la buena fe objetiva - A propósito del Proyecto de Principios latinoamericanos de los contratos' (2013) 21 Revista Chilena de Derecho Privado, pp.137-216.

15 A. Ferrante, 'Es correcta la elección del método de cálculo de la reducción del precio en los Principios latinoamericanos de Contratos?' (2014) 22 Revista Chilena de Derecho Privado, pp.9-49.

16 Á. Vidal Olivares, 'Incumplimiento contractual y pretensión de cumplimiento específico en los principios latinoamericanos de derecho de contratos (PLDC)', in A, Vaquer Aloy, E. Bosch Capdevila and M.P. Sánchez González (Eds.): El derecho común europeo de la compraventa y la modernización del derecho de contratos (Barcelona, Atelier, 2015) pp.745-765; J.S. Borghetti, 'Performance and nonperformance under the principles of Latin American Contract Law', in Momberg and Vogenauer (n. 9) $221 \mathrm{ss;} \mathrm{S.} \mathrm{Lanni,} \mathrm{'The} \mathrm{failure} \mathrm{to} \mathrm{perform} \mathrm{in} \mathrm{the} \mathrm{agreed} \mathrm{manner} \mathrm{in}$ the PLACL' (2016) 1 Osservatorio del diritto civile e commerciale, 339 ss (updated as 'The provisions on non-perfomance in the principle of Latin American contract law', in Momberg and Vogenauer (n. 9) 237 ss).

17 I De La Maza Gazmuri, "El error en los principios latinoamericanos de derecho de los contratos in Vaquer Aloy, Bosch Capdevila and Sánchez González (n. 16), 789798, N Fenoy Picón, 'La revisión del tratamiento de la imposibilidad inicial y del error en los contratos a través del análisis de diversos textos jurídicos' (2017) 70 Anuario de Derecho Civil, 2, 581 ss (initial impossibility) and 608 ss (mistake).

18 J. Cartwright, 'Defects of the contract under articles 27 to 37 of the Principles of Latin American Contract Law', in Momberg and Vogenauer (n. 9) 199 ss.

19 P.V. López Díaz, 'Por una noción amplia de lesión en el código civil chileno: una relectura a partir del principio de equilibrio contractual y la idea de excesiva desproporción contenida en el borrador de los principios latinoamericanos de contratos' (2015) in Á. Vidal Olivares, G. Severín Fuster, C. Mejías Alonzo (Eds.): Estudios de Derecho Civil X (Santiago de Chile, Thomson Reuters, 2015) 699-723; G. Caffera, 'The economic conditions of contract in South American Law: an historical approach', in Momberg and Vogenauer (n. 9) 97 ss.

20 F. De Elizade Ibarbia, 'Una aproximación española y europea al contenido del contrato. Reflexiones a la luz de los Principios Latinoamericanos de los Contratos' (2017) 70 Anuario de Derecho Civil, 3, 1139-1195; I. De la Maza, 'The notion of contract and its essential elements in the principles of Latin American Contract Law' in Momberg and Vogenauer (n. 9) 163 ss. 
21 R. Momberg, 'Formation of Contract under the Principles of Latin American Contract Law' in Momberg and Vogenauer (n. 9) 179 ss.

22 Ferrante (n. 15) 9 ss; Morales Moreno (n. 8) 227-254, R Momberg Uribe, 'Harmonization of contract law in Latin America: past and present initiatives' (2014) 19 Uniform Law Review 3 411-428 updated (as 'The process of harmonisation of Private Law in Latin America. An Overview') in Momberg and Vogenauer (n. 9) 3 y ss; Parise, Augustín, 'Harmonisation of Private Law in Latin America and the emergence of Third-generation Codes', in Momberg and Vogenauer (n. 9) 29 ss; Fenoy Picón (n. 17) 568 y ss, H Beale, 'The Principles of Latin American Contract Law: A Response of Latin American Contract Law', in Momberg and Vogenauer (n. 9) 265 ss. From a legal culture point of view: JP Schmidt, 'The Principles of Latin American Contract Law against the background of Latin American Legal Culture: A European Perspective', in Momberg and Vogenauer (n. 9) 57 ss.

23 J. Oviedo Alban, 'La convención sobre compraventa internacional y la modernización del derecho latinoamericano de contratos: Un tema pendiente', Vaquer Aloy, Bosch Capdevila and Sánchez González (n. 16), pp.769-788, P. Perales Viscasillas, 'The Principles of Latin American Contract Law and the CISG', in Momberg and Vogenauer (n. 9) 125 ss.

24 E. Hondius, 'Latin America Goes PECL' (2013) 21 European Review of Private Law, n. 2, pp.419-422; Ferrante, Alfredo, 'Quimera o Fénix? El recorrido europeo y latinoamericano hacia un derecho común de contratos' (2016) 30 Revista de Derecho Privado, 107 ss.

25 C Pizarro Wilson, 'Presentación' in Pizarro (n. 5) 15 ss; C Pizarro Wilson, 'The principles of Latin American contract law: a general introduction', in Momberg and Vogenauer (n. 9) 23. Las intervenciones del congreso de Rennes están publicadas en Revue de Droit de Contrats, n. 3, 2010, 1035 y ss.

26 Pizarro Wilson (n. 5) 9 and 15; Pizarro Wilson (n. 25) 23.

27 Pizarro Wilson (n. 5) 16.

28 Pizarro Wilson (n. 25) 24.

29 The scope of application (art. 1) and functions (art. 2) were initially all contained in art. 1. Now it is explicitly expresses the academic vocation and that, expressly do not apply to consumer contracts (see Bogota meeting, 2017).

30 See Senado Federal, Código Civil. Quadro comparativo 1912-2006 (Brasilia, Secretaria Especial de Editoração e Publicações, Subsecretaria de Edições Técnicas, 2003).

31 See v.gr. R.L. Lorenzetti (Dir) and M.F. De Lorenzo and P. Lorenzetti (Eds.) Código civil y comercial de la Nación. Comentado (Buenos Aires, Rubinzal-Culzoni, 2015).

32 About the influence of this Code: A Guzmán Brito, Historia de la codificación en Iberoamerica (Cizur Menor, Thomson Aranzadi, 2006, updated as La codificación civil en Iberoamerica. Siglos XIX y XX (Santiago de Chile, Editorial Jurídica de Chile, 2000). 
33 See Barrientos Grandon, J. (2016) El código civil. Su jurisprudencia e historia. Edición crítica, concordada y anotada (Santiago de Chile, Thomson Reuters), I, p.XIX, Guzman Brito (n. 32), passim.

34 For a comparison Ferrante (n. 27), more in general O. Lando, 'My life as a lawyer' (2002) Zeitschrift für Europäisches Privatrecht 3 508-522; O. Lando, 'European Contract Law' (1983) 31 The American Journal of Contract Law n. 4, 653 ss; K. Riedel (2000) 'The work of the Lando-Commission from an alternative viewpoint', 8 European Review of Private Law, n. 1, 79 ss.

35 In the Bogota meeting (meeting minutes 5.11.2013) binding force was introduced. The equidad was not introduced because the mayority of study group considered that it is included in the good faith.

36 For example good faith is constantly reflected in the PLACL: arts. 10, 11, 18, 19, 23, $29,37,42,48,51,54,60,76,79,109,120$.

37 Regarding to mistake (art. 28), canches of circumstances (art. 84), non-performance and time (arts. 87, 92, 93), mitigación of loss (art. 109).

38 The fact that the obligor is responsible only if he has fault is abandoned.

39 It can be material or legal impossibility and also moral impossibility: see meeting minutes 8.11.2013, Bogota.

40 Meeting minutes 9.8.2016, Santiago.

41 Meeting minutes 9.8.2016, Santiago.

42 Meeting minutes 25-27.3.2013, Buenos Aires.

43 Initially the group had substituted the term 'suspension of performance' for 'exceptio non adimpleti contractus' (defence of the unperformed contract) discussing whether these should be dealt with in two separate articles (suspension and exceptio): meeting minutes 8.11.2013, Bogota. In the final text, the reference to suspension is chosen. In part there is an influence of art. $1.168 \mathrm{CC}$ of Venezuela.

44 Meeting minutes 8.11. 2013, Bogota. Evident is the influence of art. 46.2 CISG.

45 Art. 724 CC of Paraguay expressly provides that the termination cannot be of 'minor importance', although the parties may dispose differently (art. 726). Cf Paraguayan report in Pizarro Wilson (n. 5) 464. Now also in art. 1084 Argentine Civil and Commercial Code (Argecc).

46 This solution already existed in Venezuela: meeting minutes 8.11.2013, Bogota. A lo largo de las varios borradores de los principios vienen a reestructurarse las disposiciones relativas al cambio de circunstancias (art. 84) y frustración del contrato (art. 85). Throughout the various PLACL's drafts, the provisions relating to change of circumstances (Article 84) and frustration of the cause of the contract (Article 85) has been restructured.

47 Inspired by art. 881 Argecc. 
48 The provision continues in this way: 'Notwithstanding, it does not affect the clauses agreed to by the parties for the settlement of disputes or those related to non-performance itself, or any other clause which is to operate even after the termination'.

49 This will be reflected in the official comments as established in the meeting minutes 22.8.2017, Bogota.

50 V.gr. see art. 1489 Chcc and art. 1546 Colcc, innovative trend inaugurated by PV López Díaz, 'La indemnización compensatoria por incumplimiento de los contratos bilaterales como remedio autónomo en el Derecho Civil chileno' (2010) 15 Revista Chilena de Derecho Privado, pp.65-113.

51 Cf meeting minutes 21.8.2017, Bogota.

52 Cf Art. 7.4.2 UPICC.

53 Art. 1558.1 Chcc, art. 1616.1 Colcc. However, these articles refer only to fraud, it should be noted that the gross negligence is equated (cf. Art $44.2 \mathrm{Chcc}$, Article 63 Colcc). The lack of this comparison in some Latin American countries makes introduce in the art. 107 the reference to gross negligence.

54 Cf old art. 1150 Frcc and new art. 1231-3 Frcc.

55 Cf Art. 9:503 PECL, III 3:-702 DCFR, A pesar de que el art. 7.4.4 UPICC no hace referencia a este último aspecto, podría entrar por su art. 7.4.7.

56 Art. 1558.2 Chcc, art. 1616.2 Colcc.

57 Art. 2330 Chcc, art. 2357 Colcc. The origin is art. 2199 Civil Code of Peru of 1852: J Barrientos Grandon (n. 33), II, 1095.

58 Cf Art. 9:504 PECL, III 3:-704 DCFR. Art. 7.4.7 UPICC influences the provision by the reference at that the non-performance is made 'by way of its acts or omissions'.

59 However, this has been able to find application, in the absence of an express norm, through the principle of good faith and the abusive exercise of a right.

Some provisions for special contracts or special legislation foresee it: $v . g r$. art. 1074 Colombian code of commerce (Colcom) en caso el contrato de seguro: Informe Colombia in Pizarro (n. 5), 284. Now also in the reformed art. 1710-c Argccc.

60 Inspired by art. 77 CISG (cf art. 9:505 PECL, III 3:-705 DCFR) but the reference 'the obligee is entitle to compensation for what it has allocated towards mitigating the loss, even if these measures have been ineffective' [art. 109 (2)] was introduced under the influence of art. 1211 Spanish CC modernisation proposal.

61 Art. 88: 'The obligee may not invoke non-performance due to its own acts or omissions'.

62 Meeting minutes 9-10.8.2016, Santiago of Chile.

63 Art. 112 draft 2016: Resolution and damages.

(1) If the obligee opts for the termination of a contract and enters in reasonable terms to a substitute transaction on the same object, he is entitled to damages for the 
difference between the two prices, subject to the others damages under the previous rules.

(2) If he has not made a substitute transaction, damages will be calculated on the difference between the price fixed by the contract or market place and the current price at the time of avoidance, subject to the others damages under the previous rules.

64 Meeting minutes 9-10.8.2016, Santiago of Chile.

65 Cf. meeting minutes 21.8.2017, Bogota.

66 See meeting minutes 8.11.2013, Bogota.

67 See A. Guzmán Brito, Historia de la codificación civil en Iberoamérica (Cizur Menor, Aranzadi, 2006), passim.

68 See v.gr. M. Herrera, G. Caramelo, S. Picasso, Código Civil y Comercial de la Nación. Comentado (Buenos Aires, Ministerio de Justicia y Derechos Humanos. Presidencia de la Nación, 2015); R.L. Lorenzetti (n. 34).

69 See v.gr. O. Deshayes, T. Genicon, Y.M. Lathier, Réforme du droit des contrats du régime général: commentaire article par article (Paris, Legis Nexis, 2019); F. Chénedé, Le nouveau droit des obligations et des contrats, Consolidations, Innovations, Perspectives (Paris, Dalloz, 2018), O. Deshayes, T. Genicon, Y.M. Lathier, 'Ratification de l'ordonnance portant réforme du droit des contrats, du régimen général et de la preuve des obligations. Loi n. 2018-287 du 20 Avril 2018', (2018) 18 La Semaine Juridique, 884 y ss.

70 See Guzmán ( n. 70), passim.

71 Ferrante (n. 18), 13 ss. 